\title{
OJED
}

Volume 5, Issue 1 (2020), pp. 113-117

International Journal of

Multidisciplinary Perspectives in Higher Education ISSN: 2474-2546 Print/ ISSN: 2474-2554 Online

https://ojed.org/jimphe

\section{Lessons from Yalta: Considerations for Post-Covid 19 Higher Education}

\author{
Page A. Smith \\ University of Texas at San Antonio, USA
}

\begin{abstract}
The goal of this essay is to provide Higher Education institutions with suggestions for maintaining both economic viability and organizational credibility in a Post-Covid 19 environment. Three practical, yet important, objectives for both colleges and universities are identified in light of the pandemic and its aftermath. In particular, the essay targets both administrative and stakeholder-oriented considerations for implementation.
\end{abstract}

Keywords: Higher Education, Openness, Partnerships, Technology, Trust, Yalta

On February 4, 1945, the heads of government of the United States, Great Britain and the Soviet Union met to discuss the aftermath of World War II and plan for the economic and social regeneration of post-war Europe (Roberts, 2006). Although the destruction and losses associated with the war weighed heavily on the minds of President Franklin D. Roosevelt, Prime Minister Winston Churchill and Premier Joseph Stalin, their primary goals were to reconstruct society for an age to come and form a post-war plan for global security. Throughout the meetings (there were three), frequent political positioning emerged as the "Big Three" put forth multiple options to safeguard the future (Butler, 2015). Although history confirms that the outcomes of the Yalta Conference were less than desired, the event proved solutions can emerge from carnage.

In light of the current Covid 19 pandemic and the global attempt to subdue it, it may be argued that conditions similar to those following World War II exist today. Indeed, nations are perplexed by the virus phenomenon, 
blaming occurs, partisanship invades discussions, and a myriad of opinions exist in regards to both defeating and controlling a common foe. In addition, as the virus becomes more contained, the "business of recovery" comes into focus and plans for a Post-Covid 19 recovery surface.

Most assuredly, higher education institutions are not exempt from the perils of the virus and have been extremely affected by this international "enemy". As a result of the widespread prevalence of Covid 19 and its deleterious effects on the physical, mental and economic health of higher education stakeholders, the possibility of substantial changes affecting colleges and universities looms large. Notwithstanding, this essay does not focus on current happenings and events orbiting the pandemic, but targets how higher education institutions might maintain both economic viability and organizational credibility in a Post-Covid 19 age. Hence, three salient suggestions dedicated to reestablishing the post-pandemic academy are posed for higher education administration to consider.

\section{Higher education post-Covid 19: Three considerations}

It is quite possible that the "business" of higher education will be substantially altered by the social and economic effects of the Corona Virus. As currently evidenced, the debate on both micro and macro levels continues about such matters as on-campus student residency, modalities of instructional delivery and tuition rate increases or decreases. That said, I posit three prominent themes to accent the Post-Covid 19 higher education administrative landscape: the liabilities of truth spinning, possible modalitybased university / corporate partnerships, and horizon thinking over bottom line preoccupations. Let us now turn to a brief discussion of each of these factors.

\section{Prohibit truth spinning at all costs.}

Truth spinning is defined as deception caused by adding or subtracting information while communicating with others (Hoy and Sweetland, 2001). Nyberg (1993) also refers to truth spinning or "varnishing the truth" as concealing or embellishing information, or disseminating partial information that one person or group knows while communicating with another. In other words, truth spinning is hybridizing the truth to gain favor, advantage or leverage over a person or group by purposefully deceiving them. To that end, truth spinning involves deception. And unfortunately, truth spinning is becoming a common tactic publicly utilized by politicians, corporate personalities, and the media.

Whether the method of truth spinning involves outright lying to a constituency, camouflaging issues, co-opting stakeholders through false enablement, refusing to report critical facts or manipulating circumstances to support the status quo or "party line", leaders of Post-Covid 19 higher education institutions must prohibit attempts at "varnishing" or spinning the truth in favor of openly communicating in honest and forthright ways. 
Moreover, higher education administration must make clear that any attempts to defraud internal or external stakeholders of concise and accurate information regarding the organizational situation will not be tolerated. If Post-Covid 19 higher education institutions are to meet the challenges of reinventing campus operations dedicated to new learning platforms and respond to different and more competitive market environments, the foundation for responding must be complete trust generated by full disclosure to stakeholders. In sum, higher education administration must present the "unvarnished truth" to students, parents, faculty and support personnel via the elimination and prohibition of administrative truth spinning.

\section{Consider the possibilities of Higher Education and corporate partnerships.}

As a result of the Covid 19 Pandemic, nothing in higher education has been made clearer than the prospects of increased online learning opportunities for students. Largely due to the immediate cessation of traditional campus-based, face-to-face learning situations, virtually all viable higher education entities have either entered or increased activity in online domains. Yet one important caveat is in order. The application of increased levels of online programming is not suitable to all disciplines and a onesize-fits-all mentality will prove ineffective. Thus, a careful case-by-case analysis of both academic balance and institutional fit may prove likely before changes can occur. Nevertheless, prompted by concerns over both the spread of the virus and student welfare, most colleges and universities now include robust online learning components. Notwithstanding the laudable efforts of current higher education technology personnel to respond to this online learning crisis, Post-Covid 19 requirements for online learning will far exceed current capacities. To be sure, the realities of a Post-Covid 19 higher education business is technology, and lots of it. Sophisticated technological presentations for a very tech-savvy client base will be warranted ... not the status quo. Indeed, both the depth and span of online technology (and learning) must evolve if parents are to be convinced that tuition rates for online student instruction, which are generally lower than face-to-face models, should be commensurate with those that are campusbased.

In fact, it is much more probable that modality of instruction will determine a sliding scale of tuition rates unless "new and improved" higher education online learning techniques are introduced. I agree with New York University Professor Scott Galloway's prediction that current higher education profit schemes, which unbeknownst to the general public are astronomically high (very profitable), will be reduced due to a Post-Covid 19 consumer market that doesn't invest in the premise that present online learning and campus-based endeavors are similar in both cost and benefit. In short, under the existing online learning system, higher education 
institutions will be hard pressed to "sell" students on the idea that oncampus and remote experiences are the same.

I posit alternatives exist to generating revenues in down-scaling oncampus situations versus upscaling online ones. One solution to the potential "tuition turbulence" predicament possibly confronting many Tier II, Tier III and liberal arts institutions of higher education in a Post-Covid 19 environment could be an economy of scale model, whereby the recruitment of more foreign students to online programs at lower tuition rates could assist in stabilizing revenues. However, that solution is fairly risky and short-term, given that international students generally find on-site educational experiences as much more valuable. In my estimation, a more feasible solution to a viable (and consumer attractive) online higher education presence is the formation of mutually-beneficial corporate technology partnerships with colleges and universities to expand and substantially improve online programming. Without question, firms like Apple and Microsoft have the creativity, funds, personnel and structures to respond. After all, these technology giants (and others like them) have successfully cornered the minds and markets of millions of college-aged young people with their current commercial offerings. In essence, higher education needs to let the professionals do professional things that get results. Thus, rethinking the aspects of higher education, profitability and private technology partnerships to enhance the viability of a Post-Covid 19 educational marketplace seems attractive. But at what the price? What might be sacrificed by higher education? Blended branding to include corporates with universities, fewer on-campus students, reduced tuition and fees for students who pursue online degrees and the potential of private corporations having a permanent "presence" on campuses could occur. In sum, the higher education debate about the price of accepting sacrifices such as these when considering corporate technology partnerships will likely continue into the foreseeable future. That said, at this particular time, it may be better to consider sharing profits and student access than to lose them.

3 . Focus on the horizon and not the bottom line.

Well-known leadership expert John C. Maxwell often refers to the business concepts of the "horizon" and the "bottom line" (Maxwell, 2008). In a Post-Covid 19 higher education environment, top administrative leaders need to refocus their thoughts from daily "bottom line" budgetary analyses and financial "damage control" scenarios to pursing the institutional "horizon" where central leadership is more preoccupied with visioning, planning and goal-orientations dedicated to taking their organizations to where their futures lie. Put simply, due to the pandemic, many higher education administrators were thrust into constantly monitoring the "bottom line" of budgets, payrolls and personnel. And this was the correct thing to do. They were forced to "manage" the situation closely. Most certainly, conquering a virus poses extreme challenges and requires emergency 
management. But now is a different time requiring different views. Recovering from the pandemic now requires a shift to leading rather than managing, and concentrating on moving higher education institutions to the horizon of productivity through conceptualizing and implementing new ideas related to the future of the academy under different circumstances. In sum, the time for managing what was (controlling current practices) is concluding and the opportunity for taking higher education where it belongs (leading) is at hand.

\section{Conclusions/ implications}

Just as was the case with the Big Three leaders who exited the Yalta Conference in 1945, uncertainty about what is yet to come in a Post-Covid 19 future exits. Without question, widespread higher education change looms as a possibility. This essay presents three critical considerations for higher education administration to consider as decisions about how to proceed in a Post-Covid 19 educational environment surface. To that end, it is hoped that this treatise forms a beginning of further discussions targeting higher education environments and how they may benefit all stakeholders involved in the academy.

\section{References}

Butler, S. (2015). Roosevelt and Stalin. Knopf

Maxwell, J. C. (2008) Leadership gold: Lessons I've learned from a lifetime of leading. Thomas Nelson.

Nyberg, D. (1993). The varnished truth: Truth telling and deceiving in ordinary life. University of Chicago Press

Roberts, G. (2006). Stalin's wars: From World War II to Cold War, 19391953. Yale University Press

Sweetland and Hoy (2001). Varnishing the truth in schools: Principals and teachers spinning reality. Journal of Educational Administration, 39, (3) 282-293.

Page A. Smith, PhD, is a Professor of Educational Leadership and Policy Studies at the University of Texas at San Antonio, USA. His major research interests lie in the areas of organizational climate, institutional change, trust, influence, and leadership development. Email: page.smith@utsa.edu 